Sanela Kanić*

doi: 10.19090/zop.2017.26.69-92

Vesna Kovač

UDC: $37.014: 316.32$

Univerzitet u Rijeci, Filozofski fakultet,

Pregledni rad

Republika Hrvatska

\title{
NEOLIBERALIZAM I OBRAZOVANJE U KONTEKSTU GLOBALNE OBRAZOVNE POLITIKE ${ }^{* *}$
}

\begin{abstract}
Apstrakt. Pojam globalne obrazovne politike javio se u posljednjih nekoliko desetljeća, a riječ je o fenomenu koji obuhvaća obilježja obrazovnih reformi prisutnih na globalnoj razini do kojih je došlo uslijed globalizacijskih mehanizama, odnosno opisuje ih, definira i nastoji ustanoviti tko stoji iza njihove diseminacije. Uslijed globalizacije, došlo je i do tvorbe transnacionalnog obrazovnog prostora gdje su se, uz vlade, pojavili i novi akteri, čiji su utjecaji na obrazovne politike postajali sve snažniji. Najistaknutijima se smatraju međunarodne organizacije koje različitim mehanizmima utječu na vlade mnogih zemalja, prilikom čega imaju mogućnost promicanja vlastitih agenda koje karakterizira jedna zajednička točka - neoliberalna doktrina. Pojava neoliberalizma uslijed svjetske ekonomske stagnacije sedamdesetih godina prošlog stoljeća rezultirala je prisutnošću tržišnih rješenja $\mathrm{s}$ naglaskom na učinkovitost, konkurenciju i slobodu izbora, što se, zahvaljujući globalizaciji, trajno ukorijenilo u obrazovne sustave gotovo svih zemalja. Pojave poput decentralizacije, privatizacije, novog javnog menadžmenta i novog profesionalizma postale su temelj za formiranje novih globalnih obrazovnih trendova, a uključenost privatnog sektora i redefinirana uloga vlade u pružanju i financiranju obrazovnih usluga smatra se svojevrsnim imperativom kada je riječ o neoliberalnim utjecajima na obrazovanje. Naposljetku, došlo je do prisutnosti javno-privatnih partnerstva, čija pojavnost uprizoruje prodor privatizacije i tržišnih mehanizama u obrazovanje.
\end{abstract}

Ključne riječi: globalizacija, globalna obrazovna politika, neoliberalizam, neoliberalne obrazovne reforme, javno-privatno partnerstvo.

\footnotetext{
* Sanela Kanić, sanela.kanic@gmail.com

** Ovaj rad nastao je iz okvira diplomskoga rada istog naziva, koji je izradila Sanela Kanić 2017. godine. Vesna Kovač bila je mentorica u izradi diplomskoga rada.
} 


\section{UVOD}

Polazeći od često izrečenih tvrdnji o snažnom djelovanju koje neoliberalizam i globalizacija imaju na obrazovanje i obrazovnu politiku određene zemlje, u ovom radu se prikazuju recentne akademske rasprave i osvrte o globalizacijskim procesima i neoliberalizmu te manifestiranju prisutnosti tih procesa u obrazovanju. Ponudit će se detaljniji uvid u ove fenomene, sumirati dosadašnje rasprave te identificirati i objasniti potrebe za dodatnim istraživanjima ovog fenomena.

Prikazujući dosadašnje spoznaje o neoliberalizmu i globalizacijskim procesima, fokus će biti stavljen na kontekst unutar kojeg su vođene rasprave, uočavanje prikazanih prednosti i nedostataka tih procesa iz perspektiva različitih autora, kao i uočavanje djeluju li ti procesi kao značajniji faktori u kreiranju globalne obrazovne politike. S osvrtom na pojavu i djelovanje novih aktera zainteresiranih za kreiranje obrazovnih politika, sumirat će se ključne komponente prodora neoliberalizma $u$ obrazovanju te istaknuti prednosti i nedostatke uočene prisutnosti tih procesa u obrazovanju. Za bolju ilustraciju infuzije i prisutnosti fenomena neoliberalizma u obrazovanju, komentirat će se pojavnost javno-privatnih partnerstava u obrazovanju. Odabrana komponenta posebice dobro oslikava prodor privatizacije i tržišnih mehanizama u obrazovanje. Budući da se radi o praksi koja još nije značajnije zastupljena na ovim prostorima, ponuđeni osvrt može imati i praktični doprinos dajući okvir za istraživanja i analize mogućih implikacija uvođenja takvih praksi.

\section{GLOBALIZACIJA I GLOBALIZACIJSKI PROCESI: SAŽETAK}

\section{AKADEMSKIH RASPRAVA}

Za bolji uvid u razumijevanje fenomena globalizacije korisno je opisati različite aspekte njezina djelovanja kako bi se uočilo dokud zapravo seže njezin utjecaj. Verger, Novelli i Altinyelken (2012: 3) globalizaciju promatraju kao „konstituirajući proces sve veće međuovisnosti ljudi, teritorija i organizacija u ekonomskoj, političkoj i kulturnoj domeni“،. Dok ovi autori još nisu posebno izdvojili obrazovanje kao ključnu domenu globalizacijskih procesa, može se uočiti kako su brojni drugi autori 
globalizacijske procese analizirali u kontekstu drugih, srodnih pojava, ili pak navode koji su to aspekti ljudske svakodnevice na koje globalizacija može utjecati. Razjašnjavanju koncepta doprinijet će i rasprave autora o utjecaju globalizacije na samu ulogu i status države u oblikovanju javnih obrazovnih politika, kao i na pitanja očuvanja lokalnih identiteta.

Kada je riječ o različitim aspektima djelovanja globalizacije, Dudić (2011) navodi dva pristupa koja ih pokušavaju obuhvatiti: dok prvi istražuje globalizaciju u okviru učestale međuovisnosti, novih tokova, identiteta i društvenih mreža koje ne poznaju granice, drugi se pristup odnosi na ukidanje dimenzije prostora i vremena, što omogućavaju novi komunikacijski mediji prisutni u svakodnevnim životima. Za Dalea (2000; prema Verger i sur, 2012), globalizacija znači hiperliberalizam u ekonomskom smislu, upravljanje bez vlasti u političkom smislu, te komodifikacija i konzumerizam u kulturalnom smislu. Ball (2011) u tu analizu uključuje i šire društvene pojave, tvrdeći kako srž rasprave o globalizaciji počiva na ekonomskim, političkim, kulturalnim i širim društvenim promjenama. Govoreći o ekonomskom i političkom aspektu, autor navodi sve češće pitanje koje preispituje imaju li države dovoljno kapaciteta za upravljanje vlastitim ekonomijama usprkos rastućoj moći multinacionalnih kompanija, globalnom financijskom tržištu i širenju moderne industrijske proizvodnje. $U$ analizi kulturalnog aspekta, javlja se pitanje opstanka nacionalnih i lokalnih kultura zbog homogenizacijskih efekata koje sa sobom povlače fenomeni poput amerikanizacije, holivudizacije i produciranja tzv. McDonald's svijeta (eng. McWorld), a čiji utjecaj šire globalni mediji zbog povećanog interesa prema globalnoj kulturalnoj industriji. Društveni aspekt globalizacije pak podrazumijeva promjene u prirodi interakcija i socijalizacije, što može podrazumijevati i utjecaj društvenih mreža i platforma na nove oblike komunikacije. Vidljivo je kako uslijed globalizacije dolazi do promjena čiji utjecaji neizbježno mijenjaju teksturu svačije svakodnevice, a, kao što smatra Giddens (1996; prema Ball, 2001), te promjene zahvaćaju čak i najuže sfere djelovanja.

Mnogi se autori razilaze u mišljenjima kada je riječ o opsegu promjena koje su zadesile mnogobrojne zemlje, zbog čega su politički i ekonomski aspekti, koje spominje Ball (2001), postali jedan od važnijih 
predmeta rasprave. Prema Bonalu (2003), jedna skupina autora smatra kako su globalizacijske mreže i procesi toliko moćni da dolazi do nestajanja tradicionalne države, dok druga skupina pak misli kako globalizacija jedva da mijenja njezinu ulogu. Naposljetku, javlja se i treća skupina autora koja prepoznaje utjecaj globalnih ekonomskih, političkih i kulturalnih procesa na ulogu države i ne osporava velike promjene, no ipak nije suglasna s time kako ujedno dolazi do samog raspada države. Slično razmišlja i sam Bonal (2003), koji ne osporava veliki utjecaj globalizacije, no tvrdi kako država i dalje ima ključnu ulogu u kontekstualizaciji globalizacijskih procesa, što je, prema njemu, ujedno i razlog zbog čega se globalizacijski procesi u svakoj zemlji drugačije realiziraju. Stoga, usprkos različitim pristupima pitanju odnosa globalizacije i države, koji ponajviše ovise o polazišnoj točki autora i faktorima koje uključuju u analizu, može se zaključiti kako je utjecaj globalizacije na ulogu države neosporiv.

Iako nova uloga države i izmijenjeni kapaciteti mnogima djeluju kao dovoljni razlozi za kolektivnu zabrinutost, javnost propituje i pojavu globalnog konteksta, zbog čega se ujedno javlja strah od gubitka lokalnog identiteta. Dok neki tvrde kako se on uistinu gubi, pojedini autori (npr. Amin, 1997; prema Ball, 2001; Giddens, 1996; prema Ball, 2001; Robertson, 2012; Verger i sur, 2012),smatraju kako su ti navodi - neopravdani. Naprotiv, navode kako dolazi do produciranja novog oblika lokalnog kulturalnog identiteta koji objedinjuje globalno i lokalno, a taj se proces spajanja identiteta naziva glokalizacijom (eng. glocalization). Uzevši u obzir kompleksnost tih odnosa, mišljenja su kako bi nacionalne politike trebale biti shvaćene kao proizvodi preplitanja i međuovisnosti globalnog i lokalnog, što ne eliminira lokalni identitet, već mu daje novu dimenziju.

Presjekom doprinosa različitih autora moguće je ustanoviti kako je globalizacija prisutna u mnogim područjima društvenog djelovanja, odnosno kako zahvaća političke, ekonomske, kulturalne i šire društvene procese. Budući da ta prisutnost globalizacije oblikuje svakodnevicu pojedinca kao što kreira novu ulogu države, utjecaji i promjene na području obrazovanja i obrazovne politike također su neizbježni. 


\section{KREIRANJE GLOBALNE OBRAZOVNE POLITIKE: KLJUČNI} ASPEKTI

Ustanovivši da globalizacija sudjeluje i u oblikovanju nacionalne obrazovne politike, autori su također pokušali uvidjeti na koji se način globalizacija manifestira u obrazovanju. Time su pokušali definirati globalne obrazovne reforme koje se javljaju, mehanizme kojima se šire, aktere koji sudjeluju u kreiranju obrazovnih trendova i aspekte kreiranja obrazovne politike na koje globalizacija ima utjecaj.

Naime, autori su ustanovili kako se u posljednje vrijeme provodi sve više sličnih obrazovnih reformi sa zajedničkim setom odluka diljem svijeta, pa čak i u onim dijelovima čije se kulture i stupnjevi ekonomskog razvoja uvelike razlikuju. Verger i sur. (2012: 5) taj fenomen zajedničkih obilježja obrazovne reforme nazivaju globalnim obrazovnim politikama (eng. GEP), a definiraju ga kao sve popularnije područje istraživanja unutar kojega se „,ispituju različiti načini na koje globalizacijski procesi, akteri i događaji doprinose promjeni obrazovne politike i s kojim posljedicama“. Prema brojnim autorima, pojava tzv. globalne obrazovne politike obilježila je kraj 20. i početak 21. stoljeća, a srž te pojave počiva na mehanizmima poput posuđivanja, difuzije ili konvergencije obrazovnih politika.

U svojim prikazima globalnih obrazovnih trendova i reformi, mnogi autori (primjerice, Anderson i Herr, 2015; Verger i sur, 2012) sugeriraju da su one najčešće provedene implementacijom sljedećih mehanizama: sloboda izbora škole, standardizirani kvalifikacijski testovi, povećan nadzor rada škola, sheme uvjetovane pomoći, novi javni menadžment, alternativni i ubrzani programi osposobljavanja nastavnika i ravnatelja, profesionalna odgovornost nastavnika, privatizacija, decentralizacija, javno-privatno partnerstvo, vaučeri, čarter škole, škole kao profitni centri za poduzetnike, i digitalizacija učenja pomoću virtualnih škola. Također, sugeriraju kako je sve te obrazovne trendove potrebno promatrati kroz prizmu mijenjajućeg odnosa države i obrazovanja u globalnom okruženju, zbog čega je, prije definiranja tih trendova, potrebno uvidjeti kako je do njih uopće došlo.

Jedna od značajnih zajedničkih karakteristika gotovo svih globalnih obrazovnih trendova jest prisutnost novih aktera $\mathrm{u}$ globalnom obrazovnom prostoru. Budući da se globalni obrazovni trendovi šire tako što pod 
utjecajem globalizacije i srodnih fenomena predstavnici (prosvjetnih) vlasti promatraju i posuđuju reforme prisutne u drugim zemljama, došlo je do gradnje zajedničkog obrazovnog prostora gdje se razmjenjuju obrazovne prakse. Prema Robertson (2012), formira se transnacionalna dimenzija obrazovanja, što potom dovodi do denacionalizacije nacionalnih obrazovnih sustava budući da se, uslijed pojave nekih novih aktera, o obrazovanju i razvijanju obrazovne politike prestaje odlučivati isključivo na razini države. Autorica dodaje kako se pojam 'globalno' u tom kontekstu obrazovne politike promatra i kreće na dimenzijama skale (prati se u kojoj fazi obrazovne politike i u kojoj mjeri su zastupljeni pojedini akteri) i vidokruga (prati se doseg aktivnosti određenih aktera uključenih u različite aspekte obrazovne politike).

Verger i sur. (2012) pokušali su definirati na koje sve aspekte kreiranja obrazovne politike globalizacija ima utjecaj pa su tako došli do zaključka kako je globalizacija preuzela ulogu identificiranja novih pitanja i problema koje prosvjetne vlasti, odnosno donositelji obrazovne politike trebaju riješiti. Smatraju kako globalizacija mijenja načine na koje socijalne države putem obrazovne politike pristupaju obrazovnim i drugim problemima od javnog interesa, isto kao što mijenja i njihov kapacitet za izravno pružanje i financiranje obrazovanja ${ }^{1}$. Zaključili su kako je jačanjem utjecaja međunarodnih organizacija ostvarena mogućnost mijenjanja zakonodavstva zemalja članica, čime organizacije mogu utjecati i na propise u vezi sa obrazovnom politikom. Autori također navode pojavu međunarodne povezanosti i širenja ideja, kao i transnacionalno privatno obrazovno tržište koje je nastalo otvaranjem prostora novim akterima, odnosno uključivanjem

\footnotetext{
${ }^{1}$ Primjerice, u Hrvatskoj se zamjećuje rastući trend prijavljivanja škola na natječaje za EU fondove u svrhu prikupljanja financijskih sredstava, koja se potom koriste za unapređenje pojedinih aspekata funkcioniranja škola (infrastruktura i nabava opreme, projekti namijenjeni učenicima, stručnom usavršavanju učitelja i sl). Osim toga, javljaju se i brojni projekti tehničke pomoći namijenjeni Agenciji za strukovno obrazovanje i obrazovanje odraslih kako bi se uskladio kurikulum s tržištem rada, razvila suradnja s gospodarskim sektorom, osigurala kvaliteta, itd. Ovaj trend dijelom ukazuje na pojavu drugih izvora financijske potpora za projekte i programe iz područja obrazovanja i usvajanje novih oblika poduzetničkog ponašanja odgojno-obrazovnih ustanova.
} 
privatnog sektora, a koje ujedno nadomješta i/ili se natječe protiv državnog obrazovnog sustava.

Na temelju ponuđenog prikaza, moguće je uočiti više područja putem kojih se može pratiti prodor i utjecaj globalizacije na obrazovanje. Osim što globalizacija kreira nadnacionalni prostor gdje se razmjenjuju novonastali globalni obrazovni trendovi, uvodi i nove aktere koji sudjeluju u njihovom kreiranju, diseminiranju i provođenju. Svi navedeni utjecaji i promjene mogu se razmatrati i u kontekstu vodećeg političko-ekonomskog pravca neoliberalizma. Naime, na temelju analize radova mnogih autora koji su doprinijeli proučavanju obrazovne politike, ustanovljeno je kako se u središte većine globalnih reformi stavljaju neoliberalna načela, odnosno tržišni mehanizmi i principi (mogućnost izbora, konkurencija, decentralizacija), liberalizacija (donošenje blažih zakona), privatizacija obrazovnog sektora i menadžersko upravljanje. Da bi se shvatilo zašto i kako je do tih reforma došlo na globalnoj razini, potrebno je preciznije opisati neoliberalizam i prisutnost neoliberalizma u obrazovanju.

\section{NEOLIBERALIZAM: KLJUČNI DISKURSI}

Prema Jovanoviću i Eškinji (2008), neoliberalna ekonomska doktrina javila se krajem sedamdesetih godina prošlog stoljeća kao odgovor na tadašnju svjetsku ekonomsku stagnaciju. Pobornici neoliberalizma se, prema autorima, protive svakoj intervenciji države u spontani ekonomski poredak jer su mišljenja kako intervencija prečesto uzrokuje nepredvidive i nenamjeravane posljedice. Umjesto državne intervencije, neoliberalizam se snažno oslanja na individualnu odgovornost i samostalnost, što znači da je svatko odgovoran za vlastito ekonomsko stanje s obzirom na to da prosperitet radnika ovisi o njihovoj sposobnosti trgovanja vlastitim vještinama, znanjima i poduzetničkom duhu na globalnom tržištu. Budući da, prema neoliberalizmu, prilike postoje za svakoga tko je motiviran i želi raditi, dovoljni elementi za pravednu ekonomsku neovisnost podrazumijevaju konkurentno tržište, individualnu inicijativu i državu koja se ne miješa u tržište (Alfred i sur, 2007; Ball, 1998). Osim individualne odgovornosti i samostalnosti, neoliberalizam također ističe slobodu, izbor i individualizam, 
a jedno od najznačajnijih neoliberalnih načela jest učinkovitost. S obzirom na to da se neoliberalizam javio zbog procjene državnog aparata neučinkovitim, neoliberalne reforme zahvatile su velik dio poslovanja javnog sektora kako bi se podigla učinkovitost, a, kao što je bilo i očekivano, te su promjene također zahvatile i obrazovne sustave brojnih zemalja (Friedman, 1992; Hayek, 2001; Small, 2009).

Neoliberalizam je prilično kontroverzan pojam, a stavovi prema neoliberalizmu iznimno su podijeljeni. Dok neki smatraju kako neoliberalizam omogućuje učinkovitost, prosperitet i veću slobodu izbora pojedinca, protivnici su mišljenja kako je riječ o napadu na socijalnu jednakost i pitanja od javnog interesa. Ti stavovi ujedno oblikuju i stajališta autora i javnosti kada je riječ o prisutnosti neoliberalizma u obrazovanju i obrazovnim trendovima. Drugim riječima, oni autori koji smatraju javni sektor neučinkovitim i favoriziraju tržišna rješenja najčešće odobravaju pojavu neoliberalizma u obrazovanju, za razliku od onih autora koji se protive neoliberalizmu u svakoj sferi, a naročito u obrazovnoj.

\section{NEOLIBERALIZAM I OBRAZOVANJE: IDENTIFIKACIJA GLAVNIH POJAVNIH OBLIKA}

Pojava neoliberalizma $\mathrm{u}$ obrazovanju manifestira se na različite načine, ali može se reći kako se najviše očituje u redefiniranju uloge države i uvođenju tržišnih mehanizama, u svrhu podizanja učinkovitosti obrazovnih sustava diljem svijeta. Autori koji su pratili i objašnjavali prodor neoliberalnih mehanizama u obrazovanje i pritom identificirali mehanizme koji stoje iza globalnih obrazovnih reformi, ponudili su sljedeće ključne doprinose: pojasnili su kako je uopće došlo do neoliberalizma u obrazovanju, koja su se neoliberalna načela implementirala i zašto, te koje su najistaknutije kritike usmjerene neoliberalnoj struji u obrazovnoj politici. Pritom su detaljno komentirali pojavu novih aktera u globalnoj obrazovnoj politici i njihovu ulogu $\mathrm{u}$ poticanju neoliberalnih trendova u obrazovanju. Posebna pozornost stručnjaka usmjerena je na praćenje modificiranja uloge nacionalnih vlada odnosno načina na koji se u različitim nacionalnim sustavima dočekuju i implementiraju globalni trendovi. Kao primjer 
manifestiranja prisutnosti neoliberalizma $u$ obrazovanju posebice se ističu javno-privatna partnerstva budući da je riječ o recentnom fenomenu koji obuhvaća više različitih neoliberalnih načela i procesa.

Autori su suglasni kako je prisutnost neoliberalizma u obrazovanju započela političkim usponom neokonzervativnih vlada $u$ utjecajnim zemljama, nakon čega se proširio i na ostale zemlje (Ambrosio, 2013; Martínez-Rodríguez i Fernández-Herrería, 2016; Tolofari, 2005). Autori tvrde kako su uslijed ekonomske stagnacije sedamdesetih godina mnoge vlade postale svjesne potrebe za uvođenjem velikih reformi, a određene su ekonomsko-političke grupe, neoliberali i neokonzervativci, najveći uzrok stagnacije vidjele $u$ pretjeranom uplitanju države u poduzetništvo i u tromoj javnoj upravi. To je, prema njima, rezultiralo velikim nacionalnim dugovima, visokom stopom nezaposlenosti i neučinkovitim industrijama, zbog čega je započela reforma javne uprave i svih javnih sektora, uključujući i obrazovanje. Ambrosio (2013), Hursh (2006) i Steiner-Khamsi (2006) tvrde kako te nove, neoliberalno orijentirane vlade nisu bile sklone planskoj ekonomiji, zbog čega ih obilježava uvođenje neoliberalnih reformi poput decentralizacije i privatizacije, novog javnog menadžmenta koji zagovara usmjerenost na rezultate, kao i uvođenje sustava profesionalne odgovornosti, odnosno novog profesionalizma, koji se razvio na temelju standardizacije i reformi temeljenih na ishodima.

Konkretno u obrazovanju, pojedini autori (Allais, 2012; DavidsonHarden i Majhanovich, 2004; Doherty, 2007) ističu kako je fundamentalni cilj neoliberalnih reformi bio restrukturirati obrazovanje tako da počinje doprinositi ekonomskom rastu i razvoju, odnosno da poveća konkurentnost industrija i unaprijedi kvalitetu života pojedinca.Upravo zato, Zajda (2006) navodi kako u takvoj obrazovnoj reformi svoj interes ne vidi samo privatni sektor, već i država, budući da je svakoj zemlji u interesu osigurati ekonomski prosperitet. Stoga, mnoge su zemlje počele uvoditi mehanizme poput financiranja škola na temelju broja upisanih učenika, uvođenja nacionalnog kurikuluma, provođenja nacionalnih testiranja, lokalnog upravljanja školama i periodičnog vanjskog vrednovanja škola (Doherty, 2007). Autori (Ball, 1997; Doherty, 2007; Martínez-Rodríguez i FernándezHerrería, 2016) smatraju kako je takav potez vlada dodatno stavio naglasak 
na profesionalnu odgovornost i procedure poput procjena, klasifikacija, kvantifikacija, akreditacija, standardiziranih testova, kriterija procjene, i orijentacije prema izvrsnosti, što se manifestiralo u obliku povećane konkurencije između škola i borbe za nastavak financiranja koje ovisi o uspjehu škola u privlačenju učenika. Drugim riječima, kao i sve druge dijelove javnog sektora, obrazovanje je zadesila „revolucija kvalitete“.

Ipak, za razliku od ranijih inicijativa, autori tvrde kako za unapređenje obrazovnog sustava više nije odgovorna država, već mehanizmi tržišta i konkurencije, pomoću kojih se nagrađuju učinkoviti i uspješni. Kako bi tržište i konkurencija uopće imali takvu mogućnost djelovanja, roditeljima je omogućena sloboda izbora škole, a uloga nacionalnog kurikuluma postaje osiguravanje standardizacije obrazovanja. Standardizacijom se omogućuje provođenje nacionalnih testiranja na temelju prihvaćenih obrazovnih standarda, čime se pak omogućuje mjerenje učinkovitosti i uvođenje rang lista škola. Rang liste se smatraju poželjnima jer pomoću njih tržište može pružati korisnicima potrebne informacije o konkurentnosti pojedine škole, a glavna pretpostavka je kako bi to dovelo do motiviranja lošijih škola na poboljšanje svojih usluga, dok bi se dobrim školama omogućio nastavak pozitivnog trenda. Stoga, rang liste, inspekcijski izvještaji i reputacija postali su značajne odrednice škola o kojima ovisi njihova slika i pozicija na tržištu (Ball, 1997; Doherty, 2007; Martínez-Rodríguez i Fernández-Herrería, 2016).

Uzevši u obzir sve te promjene, jedna od glavnih teza koje se vežu uz neoliberalni pokret jest, prema Tolofariju (2005), da obrazovanje postaje proizvod na tržištu koji treba biti što učinkovitiji i efikasniji, učenici postaju kupci usluga, a ponudu i potražnju određuju tržišni mehanizmi. Dolaskom novih vlada ponovno je napravljen odmak od neokonzervativnih i neoliberalnih težnji, u uvjerenju kako država ipak može pozitivno utjecati na napredak i biti mehanizam za osiguravanje socijalne kohezije i pravde. Na ovom pravcu počele su djelovati politike koje su uvele nove pojmove poput javno-privatnog, čime su se pokušale odmaknuti od kapitalističke države prema socijalnoj, a pritom ostavši u domeni podrške privatnom sektoru (Doherty, 2007; Small, 2009). 


\section{POJAVA I DJELOVANJE NOVIH AKTERA U KONTEKSTU GLOBALNE OBRAZOVNE POLITIKE I NEOLIBERALIZMA}

U svojim komentarima o načinu djelovanja neoliberalne globalne obrazovne reforme, mnogi autori nude niz detaljnijih uvida u odnos i ulogu novih aktera zainteresiranih za obrazovanje (Amaral, 2010; Anderson i Herr, 2015; Khamsi, 2006; Moutsios, 2009; Rutkowski, 2007; Small, 2009; Steiner-Verger, 2014; Verger i sur, 2012; Yang, 2010 itd). Osim države, kao najaktivniji akteri ističu se međunarodne zajednice, a u značajnoj je mjeri prisutan i privatni (profitni i neprofitni) sektor pa tako, osim korporacija i poduzeća, autori navode i industriju obrazovnih usluga koja uključuje obrazovne zaklade, specijalističke i konzultantske tvrtke, banke, lokalne konzultante, trustove mozgova, filantrope i sl.

Autori ističu kako najvažniju ulogu u globalnoj obrazovnoj politici stječu međunarodne organizacije, od kojih se kao najistaknutije navode Svjetska banka, OECD, UNESCO i WTO. S obzirom na njihov utjecaj, autori su uočili važnost definiranja funkcija, mehanizama utjecaja na vlade $\mathrm{i}$ pitanja razlikuju li se njihove agende ili pak djeluju s istim ciljem. Kada je riječ o djelovanju međunarodnih organizacija, Amaral (2010) navodi njihove tri različite funkcije: a) međunarodne organizacije kao politički instrument države, odnosno, proširenje državnog aparata; b) arene u kojima se formiraju sustavi koordinacije i pregovora među državama; c) korporativni akteri koji su razvili vlastitu obrazovnu agendu. Drugim riječima, može se reći kako međunarodne organizacije imaju različite uloge pri oblikovanju obrazovne politike, što najvjerojatnije ovisi o fazi u kojoj sudjeluju i resursima kojima raspolažu. Štoviše, kompleksnost njihove uloge i nemogućnost svođenja samo na jednu aktivnost može se iščitati u sistematizaciji Dalea (1999) koju su preuzeli i nadopunili Verger i sur. (2012). Naime, prema autorima, međunarodne se organizacije najčešće služe mehanizmima poput nametanja (neke organizacije svoju pomoć zemljama uvjetuju imperativom usvajanja određenih reformi); usklađivanja (utjecaj na zemlje koje odlučuju zajedno implementirati određenu obrazovnu politiku - npr. Europski prostor visokog obrazovanja); diseminacije (korištenje praktičnih znanja poput godišnjih izvješća i baze podataka u svrhu poticanja država na implementaciju 
pojedinih reformi); standardizacije (razvijanje principa i standarda koji se promoviraju u široj međunarodnoj zajednici - npr. PISA) i uspostavljanja međuovisnosti (poticanje država na zajedničko postizanje ciljeva kako bi se riješili problemi koji zahtijevaju međunarodnu suradnju - npr. Obrazovanje za sve).

Iako se međunarodne organizacije koriste različitim mehanizmima, ono što je im je zajedničko, barem prema većini autora, jest sama svrha uključivanja u obrazovnu politiku. Mnogi autori (Moutsios, 2009; Rutkowski, 2007; Small, 2009; Verger i sur, 2012) djelovanje međunarodnih organizacija vide kao izravno širenje globalno-neoliberalne ekonomije i promoviranje tržišne orijentiranosti, a mišljenja su kako je obrazovanje za to idealno sredstvo, budući da predstavlja strateški sektor gdje dolazi do produciranja ljudskog kapitala.

Ipak, mnogi smatraju kako se njihovi programi i načini djelovanja razlikuju. Na primjer, autori poput Lingarda (2001; prema Small, 2009), Mandala (2012) i Moutsiosa (2009) ističu kako je obrazovna agenda OECD-a produciranje ljudskih resursa koji će doprinijeti ekonomskom razvoju zemalja članica, dok s druge strane, Small (2009) i Moutsios (2009) smatraju kako je Svjetska banka usmjerena na uvođenje onih promjena koje bi građanima pomogle pri boljoj prilagodbi uzastopnim promjenama i tržištu rada. Kada je riječ o obrazovnoj agendi WTO-a, prema Vergeru (2009), njezino je postojanje upitno budući da smatra kako WTO obrazovanje vidi samo kao jednu od usluga za čiju se slobodnu trgovinu zalaže.

$\mathrm{Na}$ temelju ponuđene rasprave, može se zaključiti kako su autori suglasni kada je riječ o razmjeru utjecaja međunarodnih organizacija $\mathrm{u}$ obrazovanje, naročito u kontekstu globalizacije i neoliberalizma.

Autori (primjerice, Ball, 2001; Steiner-Khamsi, 2006; Verger, 2014; Verger i sur, 2012 itd) paralelno prate i način na koji se razvijaju i modificiraju uloge nacionalnih vlada, imajući u vidu njihove dosadašnje pozicije glavnih kreatora obrazovnih politika. Budući da su povodi za prihvaćanje aktualnih trendova različiti u različitim nacionalnim sustavima, razvila se rasprava i oko pitanja zašto ih zemlje usvajaju i kako se ti trendovi manifestiraju u odnosu na kontekstualne uvjete različitih zemalja. 
Navedeni autori upozoravaju na ključnu razliku u motivima prihvaćanja globalnih trendova između razvijenih zemalja i zemalja $u$ razvoju. Kada je riječ o zemljama u razvoju, Verger i suradnici (2012) ističu kako su u tim zemljama daleko prisutniji vanjski akteri, uzevši u obzir njihovu ovisnost o stranim stručnjacima, informacijama i izvorima financiranja. Zbog nedovoljnih resursa tih zemalja, vanjski akteri imaju mogućnost postavljanja prioriteta i smjernica, kao i kreiranja vanjskog pritiska, zbog čega se može reći kako iza dobrovoljnog usvajanja reformi zapravo vrlo često stoje sheme uvjetovane pomoći. Ipak, Verger (2014) tvrdi kako u posljednje vrijeme sve više donositelja odluka svojevoljno usvaja globalne odluke. Naime, mnogi stručnjaci smatraju kako donositelji odluka implementiraju dotične reforme ne zato što znaju, već zato što smatraju da su djelotvorne i da bi mogle odgovarati obrazovnom, političkom i ekonomskom kontekstu njihove zemlje. Ističe se kako motivi vlade za dobrovoljnu implementaciju obrazovnih politika mogu biti sljedeći: dobro oblikovane $i$ distribuirane ideje (vlade najčešće usvajaju one ideje koje su pažljivo definirane i djeluju kao najbolje ostvarivo rješenje), globalni status $i$ deteritorijalizacija (vlade često usvajaju one reforme koje imaju globalni status ili ih globalne organizacije promoviraju zato što se status globalnog najčešće percipira kao prestiž), selektivni izbor globalnih obrazovnih politika (vjerojatnije je da će vlade usvojiti one reforme koje već funkcioniraju u nekom drugom okruženju), i instrumentaliziranje globalne obrazovne politike (usvajanje određene obrazovne politike često nema za cilj samu kvalitetu, već služi kao instrument za postizanje drugih ciljeva, poput podrške pred izbore).

Ipak, autori tvrde kako je ta implementacija uvjetovana i brojnim unutarnjim faktorima poput ekonomskih, političkih i kulturalnih obilježja, zbog čega ih nije moguće u potpunosti izjednačavati. Štoviše, Ball (2011) smatra kako može čak doći i do neplaniranih posljedica ako se te različitosti ignoriraju. Budući daje to često slučaj, Verger i suradnici (2012) identificirali su četiri glavna uzroka zbog kojih implementacija globalne obrazovne politike može biti problematične prirode, naročito $u$ zemljama u razvoju. Riječ je o: resursima (velik broj zemalja u razvoju ne posjeduje adekvatne resurse za implementaciju skupih i tehnički zahtjevnih globalnih obrazovnih 
reformi, zbog čega je njihova pravilna provedba onemogućena), politici (ideologije predstavljaju ključan filter zbog kojega se određeni prijedlozi ne mogu usvojiti pravilno), kulturalnim obilježjima (autori daju primjer zemalja gdje je duboko ukorijenjen stav o javnom dobru, zbog čega je znatno teže pravilno privatizirati pojedine aspekte obrazovanja) i hijerarhiji (globalne obrazovne reforme često su osmišljene bez suradnje s nastavnicima, ravnateljima i stručnim suradnicima, što otežava njihovu uspješnu implementaciju).

$\mathrm{Na}$ temelju analize autora vidljivo je kako nadnacionalni obrazovni prostor uključuje države i vanjske aktere, od kojih svatko ima vlastite motive za suradnju kada je u pitanju obrazovna politika. Jedan od izravnijih oblika te suradnje manifestira se u fenomenu javno-privatnih partnerstva, koji podrazumijeva zajedničko djelovanje vlade i drugih partnera sa svrhom poboljšanja obrazovnih usluga i unapređenja nacionalnih obrazovnih politika, a kojega obilježavaju neoliberalni procesi.

\section{JAVNO - PRIVATNA PARTNERSTVA: PRIKAZ I KOMENTAR POSTOJEĆIH OBLIKA}

Budući da se sve veći broj vlada odlučivao na implementaciju javnoprivatnih partnerstva, autori su uočili važnost njegovog definiranja, kao i potrebu za definiranjem zajedničkih karakteristika, kategorizacijom i utvrđivanjem koji su to procesi na kojima se partnerstva zasnivaju. Konačno, uvidjevši pojavu različitih struja kada je riječ o stavovima prema partnerstvima, autori su također doprinijeli sumiranjem istaknutih stajališta o implementaciji partnerstva.

Khanom (2009) ih definira kao dugoročne, kooperativne, institucionalne sporazume između javnog i privatnog sektora, čija je svrha postizanje različitih dogovorenih ciljeva. Dok se javni sektor odnosi na vladu, privatni sektor uključuje razne profitne i neprofitne partnere. No, partnerstva su zapravo rijetko ograničena isključivo na vladu i privatni sektor, budući da u njihovoj diseminaciji i razvijanju sudjeluju i ključne međunarodne organizacije (Buenaventura, 2013; Hall, 2015; Robertson i Verger, 2012). Kada je u pitanju uzrok pojave partnerstva u obrazovanju, autori navode kako 
je do njih došlo devedesetih godina jer su predstavljali cjenovno prihvatljiv odgovor mnogih vlada na ograničene budžete ministarstva i ljudske resurse (Education International, 2009; Robertson i Verger, 2012).

Konsenzus autora o preciznoj definiciji javno-privatnih partnerstva u obrazovanju ne postoji, budući da, prema Education International (2009), postoje različite vrste partnerstva i izrazi koji se s njime povezuju. Ipak, ovisno o kompleksnosti i potrebama vlade, autori (npr. Patrinos i sur, 2009; Verger, 2012) su suglasni $\mathrm{u}$ tome kako u obrazovanju ta partnerstva obuhvaćaju aktivnosti od građenja, vođenja i održavanja infrastrukture do vođenja i provođenja obrazovnog procesa. Osim toga, partnerstva mogu podrazumijevati i opskrbu sekundarnim uslugama (knjige, školski prijevoz, obroci). No, usprkos širini pojma, LaRocque (2008) navodi kako svi ti oblici javno-privatnih partnerstva dijele sljedeće karakteristike: partnerstva su po svojoj prirodi formalna; uključuju partnere iz privatnog sektora; podrazumijevaju razvoj dugoročnog odnosa i dijeljenje rizika između partnera; fokusiraju se na ishode.

Kada je u pitanju neoliberalna podloga partnerstva, autori poput Khanoma (2009) i Vergera (2012) smatraju kako je zasnivanje partnerstva na neoliberalnim procesima evidentno usprkos težnjama pojedinih vlada prema odmaku od neoliberalizma i privatizacije. Ističu kako javno-privatna partnerstva $\mathrm{u}$ određenoj mjeri objedinjuju gotovo sve trendove povezane $\mathrm{s}$ globalizacijom i neoliberalizmom u obrazovanju: sloboda izbora škole predstavlja načelo partnerstva, a vaučeri su jedan od najučestalijih alata pri uvođenju konkurencije. Oslanjaju se i na obrazovnu decentralizaciju i privatizaciju, a naglasak se stavlja na vođenje nastavnika i kontroliranje njihova rada kako bi bili što odgovorniji prema potrebama svojih korisnika. Osim toga, autori tvrde kako se zagovaraju nagrade ovisno o uspješnosti, kao i otkazi u slučaju neuspjeha. Verger (2012) dodaje kako iza partnerstva također stoji liberalizacija obrazovnog sektora, temeljena na uklanjanju regulatornih barijera za razvoj privatnog sektora.

Kada je riječ o pojedinim vrstama javno-privatnih partnerstvima, autori fenomenu javno-privatnih partnerstva pristupaju na više različitih načina, zbog čega postoji nekoliko učestalo korištenih kategorizacija (LaRocque, 2007; LaRocque, 2008; LaRocque i Lee, 2011; Patrinos i sur, 
2009, The World Bank, 2011), koje ovise o načinu na koji je partnerstvo implementirano, kao i o prirodi propisa u zemlji koja ga usvaja. Iz postojećih kategorizacija ističe se šest tipova partnerstava čija se primjena uočava $u$ velikom broju zemalja koje su autori analizirali: infrastrukturne inicijative, ugovaranje obrazovnih usluga, privatni školski menadžment, vaučeri, filantropske inicijative, te profesionalne usluge i podrška.

- Infrastrukturne inicijative odnose se na dugoročne ugovore vlada $\mathrm{s}$ privatnim sektorom, a usmjerene su na financiranje, izgradnju, održavanje i upravljanje infrastrukturom javnih škola kao i privatno zakupljivanje objekata javnih škola.

- Ugovaranje obrazovnih usluga odnosi se najavno financirano obrazovanje koje provode privatne škole ili privatni subjekti, a može uključivati i provođenje specijaliziranog kurikuluma ili usluga poučavanja.

- Privatni školski menadžment podrazumijeva ugovorni sporazum prema kojemu su partneri iz privatnog sektora obvezni upravljati javnim školama ili pojedinim aspektima obrazovnog procesa.

- Vaučeri podrazumijevaju financijske iznose (stipendije, subvencije i porezne olakšice) koji omogućavaju učenicima (naročito niskog socioekonomskog statusa) pohađanje akreditiranih privatnih škola, a mogu biti javno i privatno financirani.

- Filantropske inicijative ${ }^{2}$ uključuju partnerstva gdje privatni subjekti pružaju pomoć u obliku stipendija, uniformi, nastavničkih bonusa, potrošnih materijala, namještaja, opreme i sponzorstva, a najviše se ističu programi usvajanja škola.

- Profesionalne usluge i podrška (jačanje kapaciteta) predstavljaju inicijative privatnog sektora koje se odnose na osposobljavanje i

\footnotetext{
2 Kao ilustracija filantropskih inicijativa u Hrvatskoj, može se navesti rad privatno financirane udruge pod nazivom Institut za razvoj i inovativnost mladih - IRIM. Uočivši važnost približavanja obrazovanja tržištu rada i uvođenja robotike i automatike u obrazovne programe, udruga donira i razvija robotiku i automatiku kod osnovnoškolskih uzrasta. Kao njihov najznačajniji odmak prema populariziranju STEM zanimanja, ističe se Croatian Makers liga, započeta 2016. godine, u kojoj se očekuje sudjelovanje preko 200 škola i drugih ustanova (Institut za razvoj i inovativnost mladih, n.d.).
} 
usavršavanje nastavnika javnih škola, kreiranje ili unapređenje kurikuluma, evaluaciju rada škole, obrazovna testiranja i dodatne usluge poput školskih obroka i prijevoza.

$\mathrm{S}$ obzirom na to koliko su te vrste partnerstva postale raširene $\mathrm{u}$ posljednjih nekoliko desetljeća, autori su također pokušali uvidjeti koji aspekti rezultiraju pozitivnim reakcijama, a koji izazivaju otpor. Analizom literature (Buenaventura, 2013; Education International, 2009; Latham, 2009; LaRocque, 2008; LaRocque i Lee, 2011; Patrinos i sur., 2009; Robertson i Verger, 2012. i Verger, 2012), vidljivo je kako zagovornici kao pozitivan aspekt postojanja partnerstva najviše ističu uključenost privatnog sektora jer se obrazovanju time doprinosi financijskim sredstvima, ljudskim resursima, stilom vođenja, inovacijama i metodama za podizanje učinkovitosti. S druge strane, vidljivo je kako za protivnike prisutnost privatnog sektora predstavlja naglasak na profit i neposvećenost problemima od javnog interesa, kao i gubitak državne kontrole zbog nedovoljne uključenosti vlade u obrazovanje. Stoga, može se zaključiti kako se prisutnost privatnog sektora ujedno ističe kao najveća prednost i najveća kritika partnerstvu.

Slična se stajališta javljaju i kada se govori općenito o neoliberalizmu u obrazovanju. Dok npr. Friedman (1992) i Hayek (2001) tvrde kako zagovornici kao najveću prednost izdvajaju učinkovitost, slobodu izbora, individualnost i poboljšavanje usluga na temelju konkurencije, značajan se broj autora (Ambrosio, 2013; Apple, 2000; Davidson-Harden i Majhanovich, 2004; Hill i Kumar, 2009; Mulheron, 2015) protivi uvođenju neoliberalnih trendova jer su mišljenja kako vrijednosti i interesi iz profitnog privatnog sektora sve više zamjenjuju kolektivne preferencije i demokratsku odgovornost obrazovnog sustava. Osim toga, mišljenja su kako neoliberalni obrazovni trendovi predstavljaju napad na egalitarističke norme, rušenje vrijednosti koje se vežu uz javne škole i sve veću stratifikaciju između bogatih i siromašnih škola. Ipak, važno je napomenuti kako postoje i autori poput Education International (2009), koji navodi kako se negativne konotacije povezane sa neoliberalizmom u obrazovanju ne mogu pripisati isključivo ideologiji, već poziva na istraživanja koja bi također ukazala na 
ograničenja pojedinih vlada zbog kojih određene reforme ne mogu biti adekvatno provedene.

\section{ZAKLJUČAK}

Analizom djelovanja brojnih procesa i pojavnih oblika globalizacije i neoliberalne doktrine na obrazovnu politiku, stručnjaci zaključuju kako je obrazovne sustave mnogih zemalja zahvatio imperativ kvalitete, učinkovitosti, fleksibilnosti i slobode izbora - ključnih neoliberalnih načela na temelju kojih su se razvili mnogi globalni trendovi. Iako su se zbog kontekstualnih faktora različito implementirali u pojedine obrazovne sustave, njihova je prisutnost potaknula mnoge autore na istraživanja i analize koji su rezultirali brojnim spoznajama o manifestaciji neoliberalizma i globalizacije u obrazovanju. Međunarodne organizacije su svojim mehanizmima, poput nametanja, standardizacije i uspostavljanja međuovisnosti, pomogle pri produciranju transnacionalnog obrazovnog prostora, što se ističe kao jedan od važnijih ishoda globalizacijskih procesa. Iako se često navodi kako su zemlje u razvoju na te trendove i deteritorijalizaciju obrazovanja pristale iz nužnosti, mnoge su se zemlje odlučile na usvajanje novih reformi iz intrinzičnih razloga. Kao što autori navode, neke su zemlje smatrale kako usvajaju djelotvorne reforme, neke je privukao globalni status tih reformi, dok su pojedine zemlje te reforme vidjele kao instrument za postizanje drugih ciljeva. Ipak, autori ističu kako implementacija pojedinih reformi može rezultirati neuspjehom, za što najviše krive nedovoljne resurse vlade, nepoklapanje zatečene ideologije i kulturalnih obilježja zemlje s principima novih reformi, kao i nedovoljnu razinu komunikacije između donositelja odluka i onih koji te odluke provode u praksi. Budući da je ključni cilj novog (globalnog) obrazovnog pokreta usmjeren prema postizanju veće učinkovitosti i kvalitete, jedno od rješenja predstavljalo je uvođenje raznih modaliteta natjecanja među sustavima i među školama, koje je trebalo poslužiti kao svojevrsna motivacija za poboljšanje. Nadalje, vlade su implementirale neoliberalne reforme poput novog javnog menadžmenta, privatizacije, decentralizacije i novog profesionalizma, a gotovo svi ti 
elementi objedinili su se u fenomenu javno-privatnih partnerstva. Iako su ona nastala s ciljem odmaka od privatizacije i neoliberalizma, autori su složni oko teze kako javno-privatna partnerstva uprizoruju suradnju vlade i vanjskih autora, pritom implementirajući glavna neoliberalna načela i mehanizme. No, prisutnost neoliberalizma u obrazovanju nije naišlo na potpuno odobravanje javnosti i obrazovnih stručnjaka. Naime, stavovi prema takvim, neoliberalnim mehanizmima i manifestacijama prilično su polarizirani. Najviše nezadovoljstva uzrokuju pojave standardizacije, usmjerenost na rezultate, nova očekivanja od nastavnika i prisutnost privatnog sektora, dok kao najveće prednosti autori ističu nove izvore financiranja, veću učinkovitost, fleksibilniju prilagodbu tržištu rada i fleksibilnije odgovaranje na potrebe učenika i roditelja.

No, analizom literature ustanovilo se kako se stajališta prema utjecajima globalizacije i neoliberalizma na obrazovanje nedovoljno temelje na rezultatima empirijskih istraživanja. Budući da je riječ o relativno recentnim pojavama, pojedini autori ukazuju na nedostatak objektivnih istraživanja implikacija neoliberalnih globalnih reformi koja se ne zasnivaju na ideološkim stavovima. Budući da je neoliberalizam i dalje vrlo kontroverzan pojam koji se često prikazuje ili kao isključivo loš ili isključivo dobar, gotovo da nema autora koji toj temi pristupa objektivno, bez da, suptilno ili ne, ukomponira i vlastiti stav prema neoliberalnoj doktrini. Stoga, ističe se potreba za empirijskim pokazateljima koji bi utvrdili konkretne posljedice neoliberalnih trendova, uzevši u obzir da ne rezultiraju nužno jednakim posljedicama $i$ da na njih utječu i navedena ograničenja vlade prilikom implementacije. 


\title{
NEOLIBERALISM AND EDUCATION IN THE CONTEXT OF GLOBAL EDUCATION POLICY
}

\begin{abstract}
The concept of global education policy has emerged in the last several decades. It is a phenomenon which includes features of globally present education reforms that have emerged due to globalization mechanisms. In other words, the task of global education policy is to describe those mechanisms, define them, as well as to try to determine who stands behind their dissemination. Globalization has also resulted in the creation of the transnational educational area where, along with the governments, new actors have emerged as well, whose influence on education policy has become more powerful over time. The most prominent are international organizations, which affect governments of many countries by enforcing various mechanisms, whereby they have the opportunity to promote their own agenda, characterized by one common point - the neoliberal doctrine. The emergence of neoliberalism, as an outcome of the World's economic stagnation in the 70's of the previous century, has resulted in the presence of free market solutions, with an emphasis on efficiency, competition and freedom of choice, which, thanks to globalization, have permanently rooted in the education systems of almost all countries. Phenomena such as decentralization, privatization, new public management, and new professionalism have become the basis for creation of new global trends in education, while involvement of the private sector and a redefined role of the government in providing and financing educational services are considered to be a sort of imperative when it comes to the neoliberal influence on education. Finally, public-private partnerships have emerged as well, whiche occurence portrays the breakthrough of privatization and market mechanisms in education.
\end{abstract}

KEY WORDS: globalization, global education policy, neoliberalism, neoliberal education reforms, public-private partnership. 


\section{REFERENCE}

Alfred, M., Butterwick, S., Hansman, C. \& Sandlin, J. (2007). Neoliberal welfare reform, poverty and adult education: identifying the problem and engaging in resistance. Predstavljeno na Adult Education Research Conference, Halifax. Manhattan: New Praire Press.

Allais, S. (2012). 'Economics imperialism', education policy and educational theory. Journal of Education Policy, 27(2), 253-274.

Amaral, M. P. (2010). Education policy and its international dimension: Theoretical approaches. Educação e Pesquisa. 36(spe), 39-54.

Ambrosio, J. (2013). Changing the subject: Neoliberalism and accountability in public education. Educational Studies, 49(4), 316-333.

Anderson, G. \& Herr, K. (2015). New public management and the new professionalism in education: Framing the issue. Education Policy Analysis Archives, 23(84), 2-6.

Apple, M. W. (2000). Between neoliberalism and neoconservatism: Education and conservatism in a global context. In: Burbules, N.C. \& Torres, C.A. (Eds.), Globalization and education: Critical perspectives (pp. 57-78). New York: Rutledge.

Ball, S.J. (1997). Policy sociology and critical social research: A personal review of recent education policy and policy research.British Educational Research Journal, 23(3), 257-274.

Ball, S.J. (1998). Big policies/small world: An introduction to international perspectives in education policy. Comparative Education, 34(2), 119130.

Ball, S.J. (2001). Global policies and vernacular politics in education.Currículo sem Fronteiras, 1(2), 27-43.

Bonal, X. (2003). The neoliberal educational agenda and the legitimation crisis: Old and new State strategies. British Journal of Sociology of Education, 24(2), 159-175.

Buenaventura, M. V. (Ed.). (2013). Gain or Drain? Understanding PublicPrivate Partnerships in Education. Phillippines: J'MAR Printing Company. 
Davidson-Harden, A. \& Majhanovich, S. (2004). Privatisation of education in Canada: A survey of trends. International Review of Education, 50(34), 263-287.

Doherty, R. A. (2007). Education, neoliberalism and the consumer citizen: After the golden age of egalitarian reform. Critical Studies in Education, 48(2), 269-288.

Dudić, M. (2001). Globalizacija i obrazovanje. Informatologia, 44(2), 137141.

Education International (2009). Public Private Partnerships in Education. Bruxelles: Education International.

Friedman, M. (1992). Kapitalizam i sloboda. Zagreb: Školska knjiga.

Hall, D. (2014). Why public-private partnerships don't work. Greenwich: Public Services International Research Unit.

Hayek, F.A. (2001). Put u ropstvo. Zagreb: KruZak.

Hill, D. \&Kumar, R. (Eds.). (2012). Global neoliberalism and education and its consequences. London: Routledge.

Hursh, D. W. (2007). Marketing education: The rise of standardized testing, accountability, competition, and markets in public education. In: Ross, E.W. \& Gibson, R.J. (Eds.), Neoliberalism and education reform (pp. 15-34). Cresskill: Hampton press.

Institut za razvoj i inovativnost mladih (n.d.). $O$ nama. 20.06.2017., http://croatianmakers.hr/hr/o-nama/.

Jovanović, M. i Eškinja, I. (2008). Neki aspekti neoliberalizma u svjetskom gospodarstvu. Zbornik Pravnog fakulteta Sveučilište u Rijeci, 29(2), 941-958 .

Khanom, N. A. (2010). Conceptual issues in defining public private partnerships (PPPs). International Review of Business Research Papers, 6(2), 150-163.

LaRocque, N. (2008). Public-private partnerships in basic education: An international review. Lincoln: CfBT Education Trust.

LaRocque, N. \& Lee, S. (2011). Non-state providers and public-private partnerships in education for the poor. Thailand: UNICEF/Asian Development Bank. 
Latham, M. (2009). Public-private partnerships in education. In: Green, R. (Eds.), Commonwealth education partnerships (pp. 158-159). London: Commonwealth Secretariat.

Mandal, S. (2012). Why learning not education?- Analysis of transnational education policies in the age of globalization. US-China Education Review, 2(3), 363-374.

Moutsios, S. (2009). International organisations and transnational education policy. Compare, 39(4), 469-481.

Mulheron, M. (2015). The impact of the USA and UK on public education in Australia. In: Little, G. (Eds.), Global education 'reform' - building resistance and solidarity (pp. 18-32). Nottingham: Russel Press.

Patrinos, H. A., Osorio, F. B. \&Guáqueta, J. (2009). The role and impact of public-private partnerships in education. Washington: World Bank Publications.

Robertson, S. L. (2012). Researching global education policy: Angles in/on/out. In: Verger, A., Novelli, M. \& Altinkyelken, H.K. (Eds.), Global education policy and international development: new agendas, issues and policies (pp. 33-51). London: Continuum.

Robertson, S. L. \& Verger, A. (2012). Governing education through public private partnerships. In: Robertson, S. L., Mundy, K., Verger, A. \& Menashy, F. (Eds.),Public private partnerships in education: New actors and modes of governance in a globalizing world (pp. 21-42). Cheltenham: Edward Elgar.

Rutkowski, D. J. (2007). Converging us softly: How intergovernmental organizations promote neoliberal educational policy. Critical Studies in Education, 48(2), 229-247.

Small, D. (2009). Neoliberalism's fate: Implications for education. Predstavljeno na ANZCIES Conference, Admidale.

Steiner-Khamsi, G. (2006). The economics of policy borrowing and lending: A study of late adopters. Oxford Review of Education, 32(5), 665-678.

Tolofari, S. (2005). New public management and education. Policy Futures in Education, 3(1), 75-89. 
Verger, A. (2012). Framing and selling global education policy: the promotion of public-private partnerships for education in low-income contexts. Journal of Education Policy, 27(1), 109-130.

Verger, A. (2014). Why do policy-makers adopt global education policies? Toward a research framework on the varying role of ideas in education reform.Comparative Education, 16(2), 14-29.

Verger, A., Novelli, M. \&Altinyelken, H.K. (2012). Global education policy and international development: an introductory framework. In: Verger, A., Novelli, M. i Altinkyelken, H. K. (Eds.), Global education policy and international development: New agendas, issues and policies (pp. 3-31). London: Continuum.

Yang, R. (2010). International organizations, changing governance and China's policy making in higher education: An analysis of the World Bank and the World Trade Organization. Asia Pacific Journal of Education, 30(4), 419-431.

Zajda, J. (2006). Decentralisation and privatisation in education: The role of the state. In: Zajda, J. (Ed.). Decentralisation and privatisation in education(pp. 3-27). Dordrecht: Springer Netherlands. 